\title{
MENSTRUAL EQUITY, ORGANIZING AND THE STRUGGLE FOR HUMAN DIGNITY AND GENDER EQUALITY IN PRISON
}

\begin{abstract}
AMY FETTIG*
INTRODUCTION

I am a lawyer, and I menstruate. I have menstruated in prisons, jails, courtrooms, legal visitation rooms, and court reporter offices. I have menstruated during court hearings, depositions, oral arguments, settlement negotiations, and prison inspections. I have passed my tampons in clear plastic bags through prison security and waited for smirking male officers to say something so I could respond forcefully without shame, but I was secretly embarrassed. I have spent long days in supermax prisons with thousands of men and wondered where I could find the closest restroom through all the locked security doors because I had a period emergency. There is a good chance that your worst period story will never beat mine. But then, we have all survived so much.
\end{abstract}

This is usually not how I introduce myself, but menstruation is a basic fact in my life and it has been a part of many of my professional and personal interactions over the years. Yet, like so many others of my generation and countless generations before mine, I generally treated my periods as a private matter - somewhat embarrassing, often inconvenient, but mostly something not to be discussed too openly. I would share a period story or two with close friends for a laugh and always offer a spare tampon or pad when asked by a female colleague - but that was pretty much the extent of my social menstruation action. If pressed, I would have said that periods were a basic biological

\footnotetext{
* Amy Fettig, Executive Director of The Sentencing Project, is a human rights lawyer and leading expert on criminal justice reform. Prior to joining The Sentencing Project, Fettig served as Deputy Director for the ACLU's National Prison Project. At the ACLU, she litigated federal class action prison conditions cases under the Eighth Amendment. Her practice focused on claims regarding medical and mental health care in prison, solitary confinement, sexual assault in detention settings, and comprehensive reform in juvenile facilities. Fettig also founded and directed the ACLU's Stop Solitary campaign seeking to end the practice of long-term isolation in our nation's prisons, jails and juvenile detention centers through public policy reform, legislation, litigation and public education. Fettig served as a leading member of the national coalition seeking to end the practice of shackling incarcerated pregnant women. Prior to law school, Ms. Fettig worked with incarcerated and formerly incarcerated women and their families in New York City. She holds a B.A., with distinction, Carleton College; a Master's from Columbia University, School of International and Public Affairs; and a J.D. from Georgetown University.
} 
fact that I treated as part of my overall health and the health of women and girls everywhere.

But I have to confess, that wasn't the full truth. If it had been, I would have been attuned to the fact that our society chooses to ignore menstruation or take any responsibility for it, that misogynistic connotations of women's long debunked mental and physical weakness still linger over the fact that we menstruate, and the idea that menstruation is somehow unclean, unsanitary, and shameful remain woven into how society talks about or fails to talk about the menstrual cycle. The mere fact that happy, glowing, pastel-colored tampon advertisements can be seen on television or Instagram hasn't changed the cultural reality of silence and stigma around menstruation - or the fundamental lack of support and dignity that our society offers to people who menstruate.

The full truth about me is that I am a civil rights litigator who represented women prisoners in class action lawsuits about unconstitutional conditions of confinement for many years before I started asking them about their periods. I asked them about their mental health care and medications, I learned about their histories of trauma and abuse, and the horror of their incarceration experiences. I talked with them about being shackled during pregnancy, pre-and post-natal care or the lack thereof, access to abortions, and visits from family. I learned a great deal about use of force and sometimes sexual abuse perpetrated by officers on incarcerated women. And I also heard a lot about bad food, filthy showers, and inadequate toothbrushes. But it took me far too long to ask about bad tampons - or the fact that it's hard to get a tampon in prison in the first place.

In retrospect, it seems incredible to me that I didn't start out asking my clients about periods in prison and no one actually brought them up for such a long time. We were trapped in the cone of silence and submission around periods that existed and still exists in too many aspects of our society. This silent submission is now even more incredible to me after the years I've spent hearing the same horror stories of menstrual mismanagement, deprivation and degradation across prisons, jails, states, and communities.

Fortunately, the silence is lifting. And the submission is fading away. For too long, the enormous impacts of menstruation on over half the population during our life cycles has been largely unaddressed in U.S. law, policy, or public consciousness. But now, the proverbial floodgates are open and they will not be closed. In the last few years, states and localities have passed laws to ensure the provision of safe, affordable, or free menstrual products; tampon taxes have been repealed; and even the infamously incompetent and misogynistic former President, Donald Trump, signed a law ensuring 
ready access to adequate menstrual hygiene products for incarcerated women in the federal Bureau of Prisons. ${ }^{1}$ But we are still at the beginning of this movement for menstrual equity. The United States remains a country where menstruating is a liability for all and a weapon and instrument of control used against many, and where equality of opportunity and dignity for those who bleed is often undermined by law, policy and practice. $^{2}$

This Essay takes a look at the movement for social change around menstruation, especially through the lens of the criminal legal system and prisons and jails in particular. Part I reviews the issues of period poverty and justice that are driving a larger social movement to recognize that safe and ready access to menstrual hygiene products should be framed through a lens of full civic participation in order to understand its full implications for the lives of people who menstruate. Part II dives into the particular needs and problems of abuse and control that incarcerated and detained people face related to menstruation. Part III examines the growing movement to transform menstruation in America along equity lines that focuses both on the rights of all menstruators while bringing social pressure to bear on behalf of the most vulnerable - incarcerated people, the unhoused, students, and those living in poverty - to demand greater governmental and cultural support for the needs, inclusion, and dignity of all people who menstruate. This Part particularly takes note of the fact that the menstrual equity movement gains strength and force when it centers the leadership and voices of people who menstruate as key players demanding social change and evolution of the culture as a whole. Part IV examines the importance of the momentum and success this social movement represents for potential litigation strategies to develop constitutional jurisprudence regarding incarcerated people and menstrual equity. It observes that the pertinent "evolving standards of decency" that inform Eighth Amendment jurisprudence must and will be influenced by the prevailing movement for menstrual equity as a deliberate strategy to ensure that incarcerated people who menstruate are not left out of the social development and rights framework that menstrual equity demands. At the same time this evolution in jurisprudence represent the opportunity for Eighth Amendment jurisprudence-and constitutional framework generally - to place a greater focus on the need for human dignity as a cornerstone of the law.

\footnotetext{
${ }^{1}$ See Part III, infra.

${ }^{2}$ See Parts I and II, infra.
} 


\section{Moving from Period Poverty to Menstrual Equity}

There are roughly two billion people on this planet who menstruate, and worldwide about 800 million people are menstruating on any given day. ${ }^{3}$ Of those daily menstruators, an astonishing 500 million people lack adequate facilities for menstrual hygiene management. ${ }^{4}$ But this is not just a problem of the developing world or countries that lack adequate resources or laws and policies that promote equality for women and girls. Many of these vulnerable people who menstruate are in the United States, where our failure to treat menstruation as a public good - whether construed as a basic human necessity, like food or medicine, or a larger social construct that demands a culture where all barriers which exclude menstruators from full civic participation are removedtranslates into social harm for all, and especially our most vulnerable people.

On average, a person who menstruates spends about 2,500 days of their life menstruating, which amounts to nearly seven years of bleeding during an average life span. ${ }^{5}$ Dealing with monthly "periods" in our lives is no small thing for myself and my fellow menstruators - but in this day and age it should not be the economic, social, cultural, and health burden it remains for most of us.

In order to remove this burden and support full and equal participation in society for people who menstruate, we need "menstrual equity." The concept of "menstrual equity," first coined by lawyer and advocate Jennifer Weiss-Wolf, ${ }^{6}$ includes the idea of menstrual products that are safe and affordable for all. But the concept goes much deeper to root out the structures that undermine the full participation of people who menstruate in society at

\footnotetext{
${ }^{3}$ Periods Don't Stop for Pandemics - Neither Will Our Efforts to Bring Save Menstrual Hygiene to Women and Girls, THE WORLD BANK (May 28, 2020), https://www.worldbank.org/en/news/feature/2020/05/28/menstrual-hygiene-day2020\#: :text=Every\%20day\%2C\%20some\%20800\%20million\%20women\%20and\%20girls\%20menstruate [https://perma.cc/FYB6-EW9N]. It is notable that this figure does not include trans-men who also menstruate. More data, analysis and action are needed to understand the full needs of this population of people who menstruate and to ensure that those needs are met.
}

${ }^{4}$ Menstrual Hygiene Management Enables Women and Girls to Reach Their Full Potential, THE WorLD BANK (May 25, 2018), https://www.worldbank.org/en/news/feature/2018/05/25/menstrual-hygienemanagement [https://perma.cc/89D2-DMUX].

${ }^{5}$ Steph Black, The Ms. Q\&A: Jennifer Weiss-Wolf on What the U.S. Can Learn from Scotland's Period Products Law, Ms. MAGAZINE (Dec. 7, 2020), https://msmagazine.com/2020/12/07/ms-qa-jennifer-weisswolf-scotland-free-period-products-menstrual-equity/ [https://perma.cc/MUH7-LS69].

${ }^{6}$ Jennifer Weiss-Wolf, Periods Gone Public XVI (2017). 
large. ${ }^{7}$ Currently, in the United States, menstrual hygiene products are not readily available and accessible in our places of work, public institutions, or public spaces. ${ }^{8}$ They are generally not allowable budgetary expenses for publicly funded schools, shelters, or crisis and emergency centers and provision is often inconsistent or coercively addressed in correction facilities and detention centers. ${ }^{9}$ Indeed, tampons and pads are actually considered a luxury good in many state tax systems, unlike food or medicine or a variety of lesser goods such as licorice, donuts, or gun club memberships, so they are subject to state sales tax. ${ }^{10}$ Despite these obvious iniquities, in 2020, thirty states still taxed menstrual hygiene products. ${ }^{11}$ It is estimated that states actually make an estimated $\$ 130$ million in tax receipts from our periods. ${ }^{12}$

This failure to recognize that menstruation is a public good that demands both material support to maintain the populations' health and hygiene while at the same time necessitating social support in order to maximize the full participation of all people in our society, implicates all of us. But it also demands that we focus on those most vulnerable to the impacts of menstrual taboos and costs. When we do that, we see that the stigma

\footnotetext{
${ }^{7} I d$. at XX-XXI.

${ }^{8}$ See, e.g., Kaanita Iyer, New Zealand Schools Will Offer Free Menstrual Products. Where Is the US on Period Equity? Far Behind, Experts Say, USA TODAY (Feb. 19, 2021), https://www.usatoday.com/story/news/nation/2021/02/19/united-states-period-poverty-free-products-tampontax-new-zealand/6797036002/ [https://perma.cc/YC5G-78VH]; Jennifer Weiss-Wolf, The Fight for Menstrual Equity Continues in 2021, MARIE ClAIRE (Jan. 27, 2021), https://www.marieclaire.com/politics/a35280718/menstrual-equity-2021-goals/ [https://perma.cc/6V9CHBJC]; Menstrual EQUiTY, ACLU, https://www.aclu.org/report/menstrual-equity [https://perma.cc/P2S8AJTS].
}

${ }^{9}$ ACLU, The Unequal Price of Periods 2-4 (Dec. 2019), https://www.aclu.org/sites/default/files/field_document/111219-sj-periodequity.pdf [https://perma.cc/KJ8ZRW27].

${ }^{10}$ TAX FREE. PERIOD., https://www.taxfreeperiod.com/ [https://perma.cc/A8V7-LYJ2] (Despite progress towards eliminating the "tampon tax" in several states over the past few years, 30 states still tax menstrual hygiene products despite the fact that they are life necessities for people who menstruate. Notably, states exempt items such as gun club memberships (WI), doughnuts (MI), private jet parts (CO), billboard advertising (AR), and licorice (AZ) but still consider tampons taxable).

1130 States Still Have Until Tax Day 2021 to Eliminate Their Tampon Tax, TAx FreE. Period. (Apr. 15, 2020), https://www.taxfreeperiod.com/blog-entries/were-demanding-that-30-states-become-tax-free-periodby-tax-day-2021 [https://perma.cc/B8T9-T9AK].

${ }^{12}$ Issues, PERIOD EQUiTY, https://www.periodequity.org/issues [ https://perma.cc/8WMY-DPM5]. 
and discrimination that menstruators face most squarely falls on those least able to defend themselves in our society and our economy.

Not surprisingly, poverty plays a leading role in determining who pays the greatest costs for the lack of menstrual equity in our society. Women are the majority of the people living in poverty in this country. ${ }^{13}$ They are often responsible not only for their own economic support, but also for the support of children and families. And tampons and pads are expensive - most women in America will pay more than $\$ 6,000$ over the course of a lifetime for menstrual products. ${ }^{14}$ For too many, this cost will necessitate a choice between basic necessities, like food for themselves and their families, and basic menstrual hygiene. These choices are exacerbated for people in poverty due to the fact that government programs, such as the Women, Infants, and Children program (WIC) and Supplemental Nutrition Assistance Program (SNAP) benefits, do not cover menstrual hygiene products. ${ }^{15}$ Due to these unsupported needs, too often low-income women report using products for unhealthily extended amounts of time or being forced to use cloth, rags, diapers, or paper as a substitute for clean tampons or pads. ${ }^{16}$ There are obvious health problems with inadequate menstrual hygiene, including urinary tract infections and bacterial vaginosis, ${ }^{17}$ but there are also social costs.

Such social costs are illustrated by the plight of students in our public schools, which largely fail to provide free and open access to menstrual hygiene products. Many poor families struggle to provide these basic items, like pads and tampons, to their children. Indeed, one in five American teenagers lives in poverty, so that lack of menstrual products can lead to compromised health, loss of classroom time, and lack of social

\footnotetext{
${ }^{13}$ Robin Bleiweis et al., The Basic Facts About Women in Poverty, CTR. FOR Am. Progress (Aug. 3, 2020), https://www.americanprogress.org/issues/women/reports/2020/08/03/488536/basic-facts-women-poverty/ [https://perma.cc/HH4F-ZRSW] (noting that, according to the most recent U.S. Census Bureau data, of the 38.1 million people living in poverty in 2018 in the United States, fifty-six percent were women.) Notably, this data pre-dates the coronavirus pandemic, which has created unprecedented and disproportionate unemployment for women.

${ }^{14}$ New Research Reveals How Much the Average Woman Spends per Month on Menstrual Products, SWNS
DigiTAL (Nov. 27, 2019), https://www.swnsdigital.com/2019/11/new-research-reveals-how-much-the-
average-woman-spends-per-month-on-menstrual-products/ [https://perma.cc/EJM7-LKFX].

${ }^{15}$ Ashley Rapp \& Sidonie Kilpatrick, Changing the Cycle: Period Poverty as a Public Health Crisis, UnIV. of Mich., SCH. OF PuB. Health (Feb. 4, 2020), https://sph.umich.edu/pursuit/2020posts/period-poverty.html [https://perma.cc/H7UP-ZUGQ].

${ }^{16}$ See id.

${ }^{17} \mathrm{Id}$.
} 
interaction. ${ }^{18}$ Where researchers have actually investigated this problem, girls report missing school due to lack of access to menstrual products, being forced to use toilet paper to staunch bleeding, and bleeding through clothes and being forced to leave school or miss classes as a result. The lifelong consequences of school absenteeism are well established - they often exacerbate performance gaps that already exist due to poverty and racism - and they raise the specter of the social disengagement and alienation that often limit overall chances in adulthood. ${ }^{19}$

Public schools are not the only government or public institutions that fail to provide for menstrual equity. The growing problems of housing instability in the United States, roughly estimated to impact over 500,000 people on any given night in $2019,{ }^{20}$ translates into an urgent need for access to menstrual hygiene products at homeless shelters and other temporary housing establishments. Lack of access to sanitary products for people who are experiencing homelessness and the need to secure scarce soap, water, and laundry facilities at the same time, are a devastating and overlooked factor in housing instability across America. ${ }^{21}$ Serious public health concerns are created by this lack of access to basic hygiene items for people experiencing homelessness-yet this issue remains largely unaddressed in most states and cities. ${ }^{22}$

Using a menstrual equity lens in our laws, policies, and practices will allow us to both expose and solve many of the underlying challenges and problems faced by vulnerable populations. For too long, the basic fact of menstruation has undermined the health and possibilities of women, girls and all people who have periods. These are social, fiscal, and human costs invisible to most of the public and previously too

\footnotetext{
${ }^{18}$ Anna North, Schools Don't Know How to Handle Girls' Menstrual Periods and Their Education Is Suffering Because of It, Vox (May 4, 2018), https://www.vox.com/2018/5/4/17311168/noble-networkcharter-schools-dress-codes-periods-chicago-menstruation [https://perma.cc/VQ4X-YLV5].
}

${ }^{19}$ ACLU, The Unequal Price of Periods 2-3 (Dec. 2019),

https://www.aclu.org/sites/default/files/field_document/111219-sj-periodequity.pdf [https://perma.cc/XNU4JA8U].

${ }^{20}$ Nat’l Alliance to End Homelessness, The State of Homelessness in America (2020), https://endhomelessness.org/homelessness-in-america/homelessness-statistics/state-of-homelessness-2020/ [https://perma.cc/T3PK-8SD8].

${ }^{21}$ Allegra Parrillo \& Edward Feller, Menstrual Hygiene Plight of Homeless Women, a Public Health Disgrace, R.I. MED. J., Dec. 2017, at 14-15.

${ }^{22}$ Liz Farmer, Menstruating While Homeless: An Ignored, Inescapable Issue, Governing (April 2, 2015), https://www.governing.com/archive/gov-homeless-women-georgia-fells-femme.html [https://perma.cc/QQZ6-FA3K]. 
stigmatized to gain sufficient attention. But this is changing as we hear more and more from directly impacted people speaking out for change. The call for change is growing, and the voices supporting it come from some of the most vulnerable and overlooked menstruators in this country.

\section{Addressing the Need for Menstrual Equity in Prisons, Jails, and Detention Centers}

The urgent need to apply a menstrual equity lens to our public institutions and our larger public agenda is especially acute in prisons, jails, and places of detention, where the needs of incarcerated and detained women and girls are often overlooked and their rights frequently undermined as a result. As Adriene Kitcheyan, a woman formerly incarcerated in the Arizona Department of Corrections, testified to the Arizona legislature about her experience menstruating behind bars, "[b]loodstained pants, bartering, and begging for pads and tampons was a regular occurrence." 23

Some of the most overlooked, vulnerable and invisible women in our society are in prisons and jails. And, yet, their numbers have been growing for decades. In 2019, approximately 222,455 women were incarcerated in prison or jail. This represents a $700 \%$ increase since $1980 .{ }^{24}$ Although women still represent a relatively small percentage of the entire incarcerated population in America, the rate of growth of female imprisonment has actually been twice as high as that of men since $1980 .{ }^{25}$ Despite this historic rise, carceral institutions have often failed to address or even consider women's unique needs.

One of those obvious needs is menstruation. Yet few states or localities have laws requiring adequate menstrual hygiene supplies in these institutions. As a result, tampons and pads in prisons and jails are frequently of poor quality and often insufficient to provide adequate hygienic protection. Women in federal custody, for example, report that maxi pads were so thin that they had to wear several at a time to prevent bleeding through their underwear. People in prison generally have limited numbers of underwear and are

\footnotetext{
${ }^{23}$ Derek Gilna, New Policies for Federal and State Prisoners Guarantee Feminine Hygiene Products, PRISON LEGAL NEws (Apr. 2, 2018), https://www.prisonlegalnews.org/news/2018/apr/2/new-policies-federal-andstate-prisoners-guarantee-feminine-hygiene-products/ [https://perma.cc/4RWT-R8XY] (explaining that Ms. Kitcheyan testified before the Arizona legislature in support of H.B. 2222, a bill to ensure free feminine hygiene products for incarcerated women).

${ }^{24}$ The Sentencing Project, Incarcerated Women and Girls 1 (2020) (on file with author).

${ }^{25} \mathrm{Id}$.
} 
only allowed to launder them on certain days, so the degrading prospect of being forced to walk around in bloody underwear is a real threat. ${ }^{26}$

The failure to require free and easy access to menstrual hygiene products behind bars also leads to inadequate supply. A first-of-its-kind, comprehensive study of women's reproductive health care in New York State correctional institutions conducted by the Correctional Association of New York found that over fifty percent of incarcerated women in the state prisons reported not getting sufficient menstrual supplies each month. ${ }^{27}$ Women in other states report similar privation; for example, women in Michigan report that a unit of thirty people was ordered to share a pack of twelve pads, ${ }^{28}$ while in an Indiana jail a woman was allowed only four pads and a tampon while she menstruated for thirty-six hours. ${ }^{29}$ Similar problems with the supply, distribution and deprivation of menstrual hygiene products were found by the Inspector General of the U.S. Department of Justice in its review of the Federal Bureau of Prisons' management of women in federal custody. ${ }^{30}$

This menstrual privation for incarcerated women is enforced on a group of people who are both vulnerable and incapable of changing their circumstances. The vast majority of women in prisons and jails are indigent before they are incarcerated, and they leave behind low-income families in the community. ${ }^{31}$ While incarcerated, women face

\footnotetext{
${ }^{26}$ See supra note 23.

${ }^{27}$ Dani McClain, Women in New York State Prions Don't Have Enough Sanitary Pads, Not to Mention Other Daily Indignities, THE NATION (Feb. 13, 2015), https:/www.thenation.com/article/archive/women-new-yorkstate-prisons-dont-have-enough-tampons-not-mention-other-daily-indignitie/ [https://perma.cc/P5MNMCJS].

${ }^{28}$ Semelbauer v. Muskegon Cnty., No. 1:14-CV-1245, 2015 WL 9906265, at*9-10 (W.D. Mich. Sept. 11, 2015).

${ }^{29}$ Lexy Gross, Suit: Clark Jail Denies Women Hygiene Products, COURIER J.

(May 31, 2016), https:/www.courier-journal.com/story/news/local/indiana/2016/05/31/suit-clark-jaildenied-woman-hygiene-products/85193988/ [https://perma.cc/4HBH-97YU].

${ }^{30}$ See U.S. Dep't of Justice, Off. of the Inspector Gen., Rev. of the Fed. Bureau of Prisons' Mgmt. of Its Female InMAte Population 29-30 (Sept. 2018), https://www.oversight.gov/sites/default/files/oigreports/e1805.pdf [https://perma.cc/QQF8-LR5T].

${ }^{31}$ Bernadette Rabuy \& Daniel Kopf, Prison of Poverty: Uncovering the Pre-incarceration Incomes of the Imprisoned, PRISON POL'Y INITIATIVE (July 9, 2015), https://www.prisonpolicy.org/reports/income.html [https://perma.cc/T2ZT-ZG3B]; Beryl Ann Cowan, Incarcerated Women: Poverty, Trauma and Unmet Need,
} 
many expenses, such as court fees, medical co-pays, and phone calls to children and family. Paying jobs are not a given in prison; with rare exceptions, prison jobs are unpaid in Alabama, Arkansas, Florida, Georgia, and Texas. ${ }^{32}$ Even if they are able to obtain a paying job while incarcerated, the average daily wage in prison is $\$ 3.45$, and many jurisdictions pay less. ${ }^{33}$ Hourly wages are also telling, while not all states inflict slave labor like Georgia or Texas, regular prison jobs in Arizona pay an hourly wage from 15 to 50 cents per hour; California is 8 to 37 cents; Illinois, 9 to 90 cents; and Connecticut 13 cents to a dollar per hour. ${ }^{34}$

In contrast to the artificially low wages in prisons and jails, the costs of basic items can be astronomical. This includes the cost of menstrual products. In Colorado, for example, a box of tampons in prison can cost a woman two weeks' wages. ${ }^{35}$ In Florida, a woman in prison may have to pay $\$ 4$ for four tampons. ${ }^{36}$ The privation inflicted on women and girls behind bars when it comes to their periods means that the state extracts unnecessary cost from women by forcing them to choose between competing goals, such as paying for medical co-pays so health can be maintained, making costly calls to children and families in order to build and maintain social ties, and maintaining adequate health and hygiene with enough pads and tampons to staunch the flow of monthly blood. The fact that these are stark and routine choices for so many women in detention settings is appalling.

Sadly, these are not even the greatest risks the lack of menstrual equity inflicts on women in carceral institutions. Because tampons and pads are not provided in a consistent and easily accessible way, products are used for too long or in unprescribed

AM. PSYCH. Ass'N (Apr. 2019), https://www.apa.org/pi/ses/resources/indicator/2019/04/incarcerated-women [https://perma.cc/QP52-XQ5L].

${ }^{32}$ Wendy Sawyer, How Much Do Incarcerated People Earn in Each State?, PRison PoL'Y Initiative (Apr. 10, 2017),

https://www.prisonpolicy.org/blog/2017/04/10/wages/\#: :text=The\%20average\%20of\%20the\%20minimum,i n\%202001\%20to\%20\%243.45\%20today [https://perma.cc/47XY-MN5C].

${ }^{33} \mathrm{Id}$.

${ }^{34} \mathrm{Id}$.

${ }^{35} \mathrm{Id}$.

${ }^{36}$ Ben Conarck, Florida Prisons Roll Out More For-Profit Services While Weighing Visitation Cuts, FLA. TiMES UNION (June 2, 2018), https://www.jacksonville.com/news/20180601/florida-prisons-roll-out-morefor-profit-services-while-weighing-visitation-cuts [https://perma.cc/Z368-HWAV]. 
ways as women attempt to adapt to privation. Making homemade tampons out of toilet paper or folded-up pads is common in women's institutions. I've seen these techniques demonstrated countless times and even taught a workshop on how to build a prison tampon with menstrual equity advocates in Washington, D.C. What began as a slightly startling exercise for the women in my workshop turned into a moment of horror as they realized the implications of using scavenged materials to staunch the monthly flow of menstrual blood. Indeed, the necessity of using unhygienic materials and wearing tampons for too long is a reality for women denied the products they need behind bars. All of this is degrading and unhygienic, but it is also dangerous, leaving incarcerated people vulnerable to reproductive tract infections and toxic shock syndrome and heightened susceptibility to STDs. ${ }^{37}$

Heightened and unnecessary health risks are a product of menstrual deprivation both inside and outside carceral institutions, but the dehumanizing power imbalances at play in places of confinement create even greater risks. Women repeatedly report having to beg officers for menstrual hygiene products while incarcerated. ${ }^{38}$ In Delaware prisons, for example, policy required women to ask officers for sanitary pads, but they were only allowed up to six pads at a time and no tampons at all. ${ }^{39}$

This artificial scarcity and the humiliating power imbalance it engenders are a toxic mixture in an institution where custody and control are already coercive - and often lacking in proper oversight. ${ }^{40}$ Sadly, the types of abuse such situations create are predictable. One high-profile example comes from the Department of Justice's investigation of Alabama's Tutwiler Prison for Women, which found that correctional officers routinely withheld menstrual hygiene products to coerce women into sex.

\footnotetext{
${ }^{37}$ See supra note 15.

${ }^{38}$ Chandra Bozelko, Prisons That Withhold Menstrual Pads Humiliate Women and Violate Basic Human Rights, The GUARDIAN (June 12, 2015), https://www.theguardian.com/commentisfree/2015/jun/12/prisonsmenstrual-pads-humiliate-women-violate-rights [https://perma.cc/Y4WC-LLPD].

${ }^{39}$ Meredith Newman, Senator Wants State to Provide Free Tampons to Women in Prison, Del. OnLINE (Apr. 16, 2018), https://www.delawareonline.com/story/news/health/2018/04/16/free-tampons-prison-delawarebill/506203002/ [https://perma.cc/KAQ5-DLAM].

${ }^{40}$ See, e.g., Michele Deitch, The Need for Independent Prison Oversight in a Post-PLRA World, 24 FED. SENT'G ReP. 236 (2012); David Fathi, The Challenge of Prison Oversight, 47 Am. CRIM. L. Rev. 1453 (2010); Michael Mushlin \& Michele Deitch, Opening Up a Closed World: What Constitutes Effective Prison Oversight?, 30 PACE L. REV. 5 (2010).
} 
Investigators found that women at the prison were forced to choose between being denied basic hygiene items for months at a time or being raped by male officers. ${ }^{41}$

Essentially, government policy in Alabama and other states creates a hierarchy of control and oppression that promotes safety and security risks for people in institutions due to a lack of menstrual equity. As Kimberly Haven, a formerly incarcerated woman from Maryland, put it, "[t]here is no dignity, no humanity, no compassion in a system that makes a person have to beg, borrow, or even make her own basic hygiene items. Pads and tampons have become weaponized." ${ }^{42}$

Fundamentally undermining the human dignity of people behind bars by weaponizing menstruation - their basic biological functions-against them is a recurrent theme for incarcerated people. From being forced to wear bloody clothes to humiliating strip searches while menstruating, the "normalization" of degradation predictably leads to massive rights violations perpetrated by institutions. A recent ruling of the U.S. Court of Appeals for the Seventh Circuit illustrates the type of extreme degradation and unlawfulness that flourishes in our carceral institutions when basic dignity is denied to people who are incarcerated. The case, Henry v. Hulett, ${ }^{43}$ involved a claim made by a class of women over the violation of Fourth Amendment rights to bodily privacy during strip searches. During the incident in question, over 200 women prisoners at the Illinois Department of Corrections Lincoln Correctional Center were subjected to abusive strip searches by a mix of correctional officers and cadets in a training exercise. During the strip searches performed by female cadets, male officers and cadets would see the women as they were strip searched and made demeaning remarks about them, calling the women "dirty bitches" and making such comments as "[n]o man wants to be with you because you smell like death," "[y]our pussy stinks," "[y]ou all are fucking disgusting," and "I

\footnotetext{
${ }^{41}$ Letter from Jocelyn Samuels, Acting Assistant Att'y Gen., to Robert Bentley, Gov. of Ala. (Jan. 17, 2014), https://www.justice.gov/sites/default/files/crt/legacy/2014/01/23/tutwiler_findings_1-17-14.pdf [https://perma.cc/3MLH-BAWA].

${ }^{42}$ Kimberly Haven, Why I'm Fighting for Menstrual Equity in Prison, ACLU (Nov. 8, 2019), https://www.aclu.org/news/prisoners-rights/why-im-fighting-for-menstrual-equity-in-prison/ [https://perma.cc/56VW-VR2Z].

${ }^{43}$ Henry v. Hulett, 969 F.3d 769, 779 (7th Cir. 2020) (explaining that the Fourth Amendment protects a prisoner's right to bodily privacy during visual inspections, subject to reasonable intrusions that realties of incarceration demand, and that "a diminished right to privacy in one's body, unlike a right to privacy in one's property and surroundings, is not fundamentally incompatible with imprisonment and is an expectation of privacy that society would recognize as reasonable").
} 


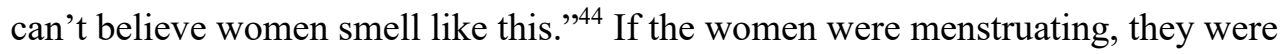
ordered to remove their hygiene products and toss them on the floor and in overflowing garbage bins in the full view of others. Women were then forced to stand barefoot on the floor dirty with menstrual blood and other bodily fluids. ${ }^{45}$ Women did not receive replacement feminine hygiene products but instead "were left to bleed on themselves for several hours, soaking through their clothes and getting blood on their legs and feet."46

The facts of Henry v. Hulett evoke revulsion for their sheer pointless brutality and routinized inhumanity and misogyny directed at the incarcerated women. The fact that the case arose from a "training" exercise is notable. But this brutality is not the product of an isolated incident in Illinois or even an especially brutal corrections system in America. Instead, it betrays the larger devaluation of women and girls in an institution that often operates outside the usual constraints of our society — but nonetheless reflects its values.

\section{Promoting a Movement for Menstrual Equity Nationwide}

Explicitly challenging these values and the misogynist and discriminatory ethos that supports them in prisons and beyond is the first triumph of the emerging movement for menstrual equity nationwide. As noted by Jennifer Weiss-Wolf in her seminal work, Periods Gone Public, "[h]ow can we imagine gender equality without menstrual equity?"47 This call for equity and equality is a notable departure from the manner in which most activists in the early twentieth century dealt with menstruation. Those efforts focused on reclaiming periods as a natural process informed by a scientific and healthfocused approach, but were still concerned with contravening the popular notions of menstruation as a dirty process designed to rid the body of impurities or "bad blood."48 Today, advocates seek to go beyond the issues of hygiene and biological process in a much more public and vocal manner that works to frame menstruation as both a dignity

\footnotetext{
${ }^{44} I d$. at 775.

${ }^{45}$ Id.; see also Matt Clarke, Seventh Circuit Holds Illinois Prisoners Retain Fourth Amendment Rights to Bodily Privacy, Overruling Circuit Precedents, Prison Legal News (Jan. 1, 2021), https://www.prisonlegalnews.org/news/2021/jan/1/seventh-circuit-holds-illinois-prisoners-retain-fourthamendment-rights-bodily-privacy-overruling-circuit-precedents/ [https://perma.cc/8VBK-CSJY].

${ }^{46}$ Henry, 969 F.3d at 775 .

${ }^{47}$ See supra note 6, at XI.

${ }^{48}$ Lara Freidenfelds, The Modern Period 38-39 (2009) (discussing the early twentieth century movement to combine science and health education as part of the public and private narrative around menstruation in America).
} 
and a civic participation issue. At the same time, these campaigns continue to focus on removing the remaining stigma of menstruation by empowering menstruators to speak up and speak out about their experience in a society that continues to ignore and marginalize their needs. ${ }^{49}$

The movement for menstrual equity in the United States focuses broadly on making safe and affordable menstrual hygiene products available by removing sales tax on those products known as the "tampon tax," as well as the provision of free and easily accessible menstrual hygiene products in public spaces and government institutions such as schools, jails, prisons, and homeless shelters. ${ }^{50}$

The fight against the "tampon tax" in the states is the fastest moving part of the menstrual equity campaign. In 2020, twenty-one states introduced bills to remove the sales tax on menstrual hygiene products; now, there are twenty states that don't tax these products, but thirty that still do. ${ }^{51}$ Efforts to bring free and accessible menstrual hygiene products to vulnerable populations and public spaces have not moved as quickly, but momentum is clear. Thirteen states now mandate free and accessible menstrual hygiene products in correctional institutions. Six have laws on free access in public schools, and one mandates such access in shelters. ${ }^{52}$ Most of these gains were made in just three years between 2016 and 2019 with the legislative cycle in the states largely consumed by the COVID-19 pandemic in 2020. Fortunately, in 2021, menstrual equity campaigns are again moving forward, with twenty bills introduced in nine states by March $2021 .{ }^{53}$

There is also growing support for menstrual equity among voters. Indeed, polling research in 2018 by the Justice Action Network found that an overwhelming ninety

\footnotetext{
${ }^{49}$ See, e.g., supra note 6, at 121-55.

${ }^{50}$ Notably, other nations are addressing menstrual equity with a broader lens. In 2020, Scotland became the first nation in the world to mandate that all period products in the country will be free for anyone who needs them. Li Cohen, Scotland Becomes $1^{\text {st }}$ Country to Make Period Products the Law, CBS News (Nov. 25, 2020), https://www.cbsnews.com/news/free-period-product-scotland/ [https://perma.cc/2E5Z-URGX].

${ }^{51}$ See PERIOD EQUiTy, http://www.periodequity.org [https://perma.cc/4HRJ-5TU3].

${ }^{52}$ See supra note 19 , at 7.

${ }^{53}$ Jamie McConnell, Updates on Menstrual Equity Policies, Women's VoICES FOR the EARTH (Jan. 11, 2021), https://www.womensvoices.org/2021/01/11/period-health-policies-is-your-state-working-to-makemenstrual-equity-a-priority/ [https://perma.cc/4LFL-ZU2U].
} 
percent of voters across the political spectrum were in favor of providing free menstrual products in prison. ${ }^{54}$

Federal legislation is also driving change. Notably, the First Step Act of 2018 ensures that people incarcerated in federal prisons have adequate access to menstrual hygiene products. ${ }^{55}$ Building on this recognition of menstrual hygiene products as a medical necessity rather than a "luxury" item, the CARES Act of 2020 reclassified menstrual products as "qualified medical expenses" under the IRS tax code so that they can now be bought with FSAs and HSAs pre-tax, like other long-eligible expenses such as contact lens solution and sunscreen. ${ }^{56}$ Finally, legislation introduced by U.S. Representative Grace Meng (D-NY), the Menstrual Equity for All Act, requires comprehensive and expanded support for menstruation, including provisions that require Medicaid to finally cover menstrual products, the inclusion of menstrual products as part of school budgets, the mandatory provision of menstrual products for certain employers, and requirements that states provide menstrual products in correctional institutions in order to receive federal criminal justice funding. ${ }^{57}$

The emphasis of these largely legislative campaigns is social equity and a recognition that vulnerable populations suffer the most in systems of inequality. ${ }^{58}$ This is notable in

\footnotetext{
${ }^{54}$ Grace Meng, Julissa Ferreras-Copeland \& Jennifer Weiss-Wolf, Women Are Finally Winning the Period Rights Fight, NEwsweEK (Jan. 25, 2018), https://www.newsweek.com/women-finally-winning-period-rightsfight-790990 [https://perma.cc/7M7Z-QEXQ].
}

${ }^{55}$ P.L. 115-391; see also Anjana Samant, The First Step Act is a Small Step for Incarcerated Women, ACLU (Dec. 27, 2019), https://www.aclu.org/blog/prisoners-rights/women-prison/first-step-act-small-stepincarcerated-

women\#: : text=The $\% 20$ First $\% 20$ Step $\% 20$ Act $\% 20$ moves,period $\% 20$ thereafter $\% 2$ C $\% 20$ with $\% 20$ some $\% 20$ ex ceptions [https://perma.cc/2QDS-S6LN].

${ }^{56}$ IRS Outlines Changes to Health Care Spending Available Under CARES Act, IRS (June 17, 2020), https://www.irs.gov/newsroom/irs-outlines-changes-to-health-care-spending-available-under-cares-act [https://perma.cc/3BFX-MXHM].

${ }^{57}$ Menstrual Equity for All Act of 2019, H.R. 1882; see also Press Release, Grace Meng, Member, U.S. House of Representatives, Meng Unveils Bold Proposal to Provide Menstrual Equity to All, (Mar. 26, 2019), https://meng.house.gov/media-center/press-releases/meng-unveils-bold-proposal-to-provide-menstrualequity-to-all [https://perma.cc/MHD9-TXHV].

${ }^{58}$ See, e.g., Jennifer Weiss-Wolf, U.S. Policymaking to Address Menstruation: Advancing an Equity Agenda, 25 WM. \& MARY J. RACE, GeNDER \& Soc. JUST. 493, 495-501, 505-514 (2019); Jennifer Weiss-Wolf, The ERA Campaign and Menstrual Equity, 43 N.Y.U ReV. L. \& Soc. Change 168, 169-173 (2019); Emily McCarty, Let It Flow! NYC Funds Free Pads and Tampons for All Schools, Jails, and Shelters, BitCH MediA (June 29, 2016), https://www.bitchmedia.org/article/let-it-flow-nyc-funds-free-pads-and-tampons-all-schools- 
the statements of law makers who introduce and support menstrual equity legislation requiring government to provide free and easy access to menstrual hygiene products. For example, in a statement proposing New York City's first-of-its-kind legislation in 2015 providing free menstrual hygiene products in schools, shelters, and jails, New York City Council member Julissa Ferreras-Copeland stated, "When over half of New York City's residents experience menstruation, it is crucial to acknowledge their needs and show value and respect for their bodies by making menstrual hygiene products widely and easily available. ... No student, homeless individual or inmate should have to jump through hoops, face illness or feel humiliated because they cannot access pads or tampons. $" 59$

This framing of the menstrual equity movement that centers dignity issues is increasingly part of the messaging coming from state and local movements that are being led and driven by directly impacted people. One such example is the Maryland Reproductive Justice Inside Coalition, which worked for passage of the state's law mandating the provision of free and adequate tampons and pads to incarcerated women in state and local correctional facilities. ${ }^{60}$ The Coordinator of that coalition, Kim Haven, a formerly incarcerated woman who personally experienced severe health consequences from the state's refusal to provide adequate menstrual hygiene products, spoke passionately for women on the inside. Part of that campaign featured Ms. Haven demonstrating exactly how incarcerated women put together homemade prison tampons. ${ }^{61}$ Today's menstrual equity activism uses frank and unapologetic statements to counter the stigma and shame that silenced discussion of menstruation in earlier times.

\footnotetext{
jails-and-shelters [https://perma.cc/K2VH-PMMJ]; Melissa Jeltsen, Providing Free Pads and Tampons to Incarcerated Women Is About More than Hygiene, HufF. Post (June 23, 2016), https://www.huffpost.com/entry/new-york-prisons-periods_n_576bfcade4b0b489bb0c901b [https://perma.cc/6WA7-Z2H7].

${ }^{59}$ Melissa Jeltsen, Providing Free Pads and Tampons to Incarcerated Women Is About More than Hygiene, HuFF. Post (June 23, 2016), https://www.huffpost.com/entry/new-york-prisonsperiods_n_576bfcade4b0b489bb0c901b [https://perma.cc/CM3L-BQQ6].

${ }^{60}$ K. Haven, Incarcerated People Deserve the Dignity of Menstrual Equity, Ms. (Nov. 15, 2019), https://msmagazine.com/2019/11/15/incarcerated-people-deserve-the-dignity-of-menstrual-equity/ [https://perma.cc/DLH4-M5EC].

${ }^{61}$ See NARAL Pro-Choice Maryland, Turning a Pad into a Tampon, YouTube (Apr. 3, 2018), https://www.youtube.com/channel/UCPY-Zz3AlpRjHcJWuh3cMkg/videos [https://perma.cc/C572-L4YC]. The author wishes to express her personal thanks to Ms. Haven for coaching her through various tampon making techniques in prison.
} 
Dignity and the full civic participation that dignity requires can only be achieved with an end to shame.

Another example of the type of robust organizing to end menstrual shame and emphasize dignity as part of state legislative efforts is the \#LetItFlow social media campaign that emerged in Arizona. A menstrual equity bill introduced by Representative Athena Salman in 2018 was meant to provide adequate and unhampered access to menstrual hygiene products in state prisons. In introducing the bill, Rep. Salman stated, "This issue speaks to the basic dignity of being a woman. By denying women additional pads and no free tampons, that is violating a woman's dignity and that's fundamentally wrong." In her introduction, the lawmaker further noted that the state's current policy allowed for only twelve pads a month — regardless of need — and that incarcerated women in the state were paid just fifteen cents an hour, so buying a 16-pack of pads from the prison commissary at $\$ 3.20$ or a 10 -pack of tampons at $\$ 2.05$ was beyond the means of most people. ${ }^{62}$

The bill first had a hearing in front of an all-male legislative committee, during which the committee chair, Jay Lawrence, expressed his apparent inability to understand the seriousness of menstrual hygiene and the problems deprivation and the resulting coercion created in prison settings. He stated, "I'm almost sorry I heard the bill. . . . I didn't expect to hear pads and tampons and the problems of periods. ${ }^{.63}$ Fortunately, not everyone on the committee reacted in such a puerile fashion, and the bill passed out of committee 5-4. It then stalled, however, when the Chair of the Rules Committee, Rep. Thomas "T.J." Shope, refused to give the bill a hearing, claiming that the Department of Corrections was voluntarily changing its policy ${ }^{64}$ As a result of Rep. Shope's actions, the \#LetItFlow campaign emerged, with women across Arizona sending tampons and pads to

\footnotetext{
${ }^{62}$ Amir Vera, Why Women in Arizona Are Sending a State Representative Pads and Tampons, CNN (Feb. 13, 2018), https://www.cnn.com/2018/02/13/health/women-pads-arizona-state-representative-trnd/index.html [https://perma.cc/8NRM-8B7J].

${ }^{63}$ Jimmy Jenkins, Pads and Tampons and the Problems with Periods: All-Male Committee Hears Arizona Bill on Feminine Hygiene Products in Prison, KJJZ (Feb. 5, 2018), https://kjzz.org/content/602963/pads-andtampons-and-problems-periods-all-male-committee-hears-arizona-bill-feminine [https://perma.cc/3G8RUVCE].

${ }^{64}$ Amy Held, Arizona Department of Corrections Changes Sanitary Pad Policy Following Backlash, NPR (Feb. 15, 2018), https://www.npr.org/sections/thetwo-way/2018/02/15/586134335/arizona-department-ofcorrections-changes-sanitary-pad-policy-following-backlash [https://perma.cc/B6RS-AH9Y].
} 
his office and calling him out - often with pictures of themselves holding menstrual hygiene products—on Twitter using the \#LetItFlow hashtag. ${ }^{65}$

The outrage and creativity of this effort is a hallmark of the fearless organizing that has emerged around menstrual equity. But the result is also a cautionary tale. There is still no menstrual equity law in Arizona. Lawmakers conceded to the reassuring words of the Department of Corrections rather than establishing a legal right for people who menstruate to receive adequate hygiene products that are a basic necessity for their health and dignity. As former counsel for all women incarcerated in state prisons in Arizona in the case Parsons v. Ryan, which alleges constitutionally inadequate health care and conditions ${ }^{66}$ I can also say that implementation of the menstrual products policy was spotty at best. Women incarcerated in those facilities continue to face health, hygiene and dignity problems because there is no law to protect them or hold the prisons accountable for recognizing their right to menstrual equity.

The growing strength of the menstrual equity movement nationwide is a welcome sign for increased gender equity and social inclusion for all people in America. Building and sustaining these state level movements until rights are established and menstrual equity becomes a basic fact in the culture will be necessary. At the moment, however, menstrual equity is more about what state or jurisdiction you live in than it is a bedrock principle of our republic. The Constitution has yet to play a leading role as part of this movement.

\section{Litigating Menstrual Equity in Prisons and Jails - Evolving Standards of Decency and Dignity}

In a republic, such as the United States, justice by geography is a recurrent problem - too often rights depend more upon the state or locality you live in than underlying notions of universal human rights or dignity or indeed the social good. Are you "lucky" enough to live in a jurisdiction that cares for your rights and well-being, or are you trapped by birth or circumstance in a place that cares little for you or actively seeks to undermine your rights and deny you dignity? At present, location remains too much a factor in the fight for menstrual equity. As discussed in Part III, supra, some states and jurisdictions are enacting legislation to protect menstruators and ensure that people who menstruate in public institutions, such as jails, prisons, homeless shelters, or

\footnotetext{
${ }^{65}$ Vera, supra note 62.

${ }^{66}$ Case Page, Parsons v. Ryan, ACLU, https://www.aclu.org/cases/parsons-v-ryan [https://perma.cc/HG8DJXTK].
} 
public schools, have ready access to menstrual hygiene products. Yet the majority still offer no protection and rights remain patchy at best. This is the scenario in which litigation, and constitutional challenges in particular, can play a significant role in ensuring that rights for some become rights for all.

Places of incarceration in particular often need the force of law and constitutional standards to evolve away from brutal, unjust, and inhumane practices. But what might a civil rights litigation strategy to support menstrual equity in jails and prisons look like? The Eighth Amendment to the U.S. Constitution prohibits the infliction of "cruel and unusual punishment" on prisoners, ${ }^{67}$ and long-established caselaw makes clear that the deprivation of prisoners' "basic human needs," such as shelter, food, clothing, sanitation, and hygiene, can violate Eighth Amendment prohibitions. ${ }^{68}$ It's clear that menstrual hygiene is a basic need for all people who menstruate. Similarly, the Eighth Amendment also requires that prisoners be given adequate medical care for serious medical needs. ${ }^{69}$ Notably, the Eighth Amendment also protects prisoners from conditions that put them at serious risk of injury. ${ }^{70}$ As discussed supra in Parts I and II, there are well-established and severe health risks for people who are forced to use inadequate, unsanitary products

\footnotetext{
${ }^{67}$ Notably, pretrial detainees in jails have not been convicted of any crime so they are not prisoners. The Supreme Court established a means for pretrial detainees to challenge conditions of confinement under the substantive Due Process Clause of the Fourteenth Amendment. See Bell v. Wolfish, 441 U.S. 520 (1979). Although the Bell standard is well-established, courts are not in agreement as to whether the standard is different than the Eighth Amendment or affords any additional protections. See, e.g. Board v. Farnham, 394 F.3d 469, 478 (7th Cir. 2005) (finding it "convenient and entirely appropriate" to apply the same standard to claims arising under the Fourteenth Amendment (detainees) and the Eighth Amendment (convicted prisoners)); Cook v. Sheriff of Monroe County, 402 F.3d 1092, 1115 (11th Cir. 2005) (holding that in regard to providing pretrial detainees with basic necessities, the minimum standard allowed by the due process clause is the same as that allowed by the eighth amendment for convicted prisoners); A.M. v. Luzerne County Juvenile Detention Center, 372 F.3d 572, 584 (3d Cir. 2004) (acknowledging that pretrial detainees claims are properly analyzed under the Fourteenth Amendment yet indicating that due process obligations with respect to medical care had not been defined by the Supreme Court and holding that what is clear is that detainees are entitled to no less protection than a convicted prisoner is entitled to under the Eighth Amendment); but see Kingsley v. Hendrickson, 135 S.Ct. 2466 (2015) (applying an objective reasonableness standard for pre-trial detainee's use of force claim under the Fourteenth Amendment's Due Process Clause in contrast to the more onerous subjective standard for convicted prisoners under the Eighth Amendment).

${ }^{68}$ See, e.g., Rhodes v. Chapman, 452 U.S. 337, 346 (1981).

${ }^{69}$ See, e.g., Estelle v. Gamble, 429 U.S. 97, 103 (1976).

${ }^{70}$ See, e.g., Helling v. McKinney, 509 U.S. 25 (1976).
} 
to deal with menstruation, and these conditions are common in American prisons and jails. $^{71}$

Despite the fact that menstrual hygiene would seem to fit squarely within the existing boundaries of Eighth Amendment jurisprudence as either a basic human need or serious medical need, very few lawsuits have addressed the denial of menstrual products, and even fewer have been successful. An older case, Dawson v. Kendrick, out of the federal district court in West Virginia, did find an unconstitutional denial of hygiene products including sanitary napkins at a county jail, but without much analysis of the issue. ${ }^{72}$ More recently, a federal district court in Michigan found that denying menstrual products to incarcerated women for up to two days, which caused them to bleed through their clothes and remain in blood-stained uniforms until the weekly laundry day, was not a violation of the Eighth Amendment but rather a minor "delay in delivery."73 In addition to claims about lack of access to menstrual hygiene products, that case, Semelbauer v. Muskegon County, included claims related to male officers routinely viewing naked and partially naked women detainees while they attempted to shower, dress, or use the toilet, and the jail's failure to provide women exercise outside their cells. ${ }^{74}$ This typifies the fact that where institutions deny women the basic dignity of menstrual hygiene, there is often a larger context of gender-based oppression and coercion in the institution, as well as other unconstitutional conditions. The failure to treat people with human dignity is a systemic problem that manifests itself in all aspects of prison and jail administration; it is rarely ever a one-off.

\footnotetext{
${ }^{71}$ It should be noted that the legal test for finding a violation of the Eighth Amendment has both an objective and a subjective component. In order to meet objective requirement a claimant must show that the condition or conditions being challenged seriously affect health or safety, e.g., that you are being deprived of a basic human need or exposed to serious harm, as discussed above. The subjective part of the test requires that a claimant show that the officials being sued acted with "deliberate indifference" meaning that the official knew of the condition and did not respond in a reasonable manner. This seminal test is set forth in Farmer $v$. Brennan, 511 U.S. 825 (1994). In the context of menstrual equity issues, one can imagine demonstrating that prison officials are aware that their policies and practices related to menstrual hygiene products for menstruating prisoners were inadequate, putting people at risk, and actually causing harm. Notably, "deliberate indifference" can be inferred by the very fact that the risk of harm is obvious. Id. at 842.

${ }^{72}$ Dawson v. Kendrick, 527 F. Supp. 1252, 1288-89 (S.D.W. Va. 1981).

${ }^{73}$ Semelbauer v. Muskegon Cnty., No. 1:14-CV-1245, 2015 WL 9906265, at*9-10 (W.D. Mich. Sept. 11, 2015).

${ }^{74}$ Complaint, Semelbauer, No. 1:14-CV-1245 (W.D. Mich Dec. 4, 2014).
} 
The lack of existing caselaw - or even challenges to the problem of menstrual hygiene in prisons in jails - is likely in part because of the issue I addressed at the beginning of this Essay. Simply put, lawyers weren't asking about this issue until recently, and incarcerated people weren't talking about it - at least not to lawyers. It is also true that litigation on behalf of women in women's prisons is fairly rare. For example, as the former Deputy Director of the ACLU's National Prison Project (NPP), the only national legal organization that focuses solely on prison litigation, I know that NPP brought only one class action case against a women's prison from 2001 to 2020 . We did represent women class members in statewide cases or in units in jails, but these cases did not tend to focus on women's particular issues - at least at the outset of the litigation. This is not an uncommon pattern in prison litigation generally. Litigators have tended to focus on men's prisons. Part of this is just a numbers game - there are so many more men in prison and hence so many more men's prisons as potential litigation targets. ${ }^{75}$ But there is likely more going on here than just numbers. Corrections in the United States is built by and for men, and the concerns of those institutions reflect the larger society's concerns. Menstrual equity, or even the provision of adequate pads or tampons, was not a concern of prisons or jails or the community at large - until now.

That shift can be seen in the actual result of the Semelbauer case. Despite the district court's dismissal of the menstrual hygiene claim, the parties were able to reach a settlement that included access to menstrual products on a daily basis at the Muskegon County Jail in addition to addressing other systemic problems. ${ }^{76}$ It's pure speculation as to why this remedy was included in the settlement. Perhaps it was the negative press the facility received for denying adequate pads and tampons? Or maybe dedication to the issue on the part of the plaintiffs' attorneys? Or simple recognition by jail administrators or community leaders that the practice was inhumane, disgusting, or bad for security? Perhaps it was a combination of all of these. Regardless of the motivations, the change in policy and practice in Muskegon County Jail happened against the backdrop of the growing public recognition that menstrual hygiene and the human dignity issue it represents must be addressed. This is significant for the law and litigation strategy.

\footnotetext{
${ }^{75}$ Women make up a little over ten percent of the incarcerated and detained population in adult prisons and jails in the United States. See Danielle Kaeble \& Lauren Glaze, Correctional Populations in the United States, 2015, BuREAU OF JuST. StAT. (Dec. 2016), https://www.bjs.gov/content/pub/pdf/cpus15.pdf [https://perma.cc/MJL9-6TSJ].

${ }^{76}$ Mistreatment of Women at the Muskegon County Jail, ACLU OF MicH., https://www.aclumich.org/en/cases/mistreatment-women-muskegon-county-jail [https://perma.cc/K2V49K2B].
} 
Longstanding precedent establishes that the Eighth Amendment's prohibition against cruel and unusual punishment is not static. Rather, its jurisprudence must be informed by "the evolving standards of decency that mark the progress of a maturing society." "evolving standards of decency" are subject to an increasingly sophisticated analysis by the courts, and the U.S. Supreme Court in particular, which has looked at a number of objective factors including legislative change, states laws, expert opinions and social science research, professional standards, geographic isolation of practices, and international and comparative law. ${ }^{78}$

The growing movement nationwide, and in particular states, to demand menstrual equity and pass laws to enforce the availability of safe, affordable, and free menstrual hygiene products for vulnerable populations like incarcerated people, is certainly a marker of "evolving standards of decency." This argues for a litigation strategy that is tied to local and state organizing for menstrual equity laws and practices, as well as the larger national movement to expose and promote the need for menstrual equity in our society writ large.

At the same time, the menstrual equity movement's emphatic emphasis on concepts of human dignity for women, girls, and all people who menstruate ${ }^{79}$ is particularly pertinent in the context of Eighth Amendment litigation strategy and the rights of incarcerated people. In the context of prisoner rights jurisprudence, the concept of human dignity in the Eighth Amendment ${ }^{80}$ has been used to place limits on punishment, such as

\footnotetext{
${ }^{77}$ Trop v. Dulles, 356 U.S. 86, 101 (1958).

${ }^{78}$ See, e.g., Hall v. Florida, 134 S. Ct. 1986, 1993-2000 (2014) (finding Florida law's restrictive approach to recognizing an individual's intellectual disability when seeking execution to be unconstitutional under the Eighth Amendment in light of both current standards, other state practices, research, and principles and the court's independent judgment in order to implement the court's prior holding in Atkins that people with intellectual disabilities should not be subject to the death penalty); see also Matthew C. Matusiak et al., The Progression of "Evolving Standards of Decency" in U.S. Supreme Court Decisions, 39 CRIM. Just. Rev. 253, 260-61 (2014).

${ }^{79}$ See supra Part III.

${ }^{80}$ The concept of "human dignity" is a surprisingly recent concept in constitutional jurisprudence in this country. It first emerged as a value relevant to interpreting the Constitution and vindicating individual rights in the post-World War II era in the wake of the horrors of the Holocaust, the evolution of the international human rights movement, and the United States' commitment to the United Nations and the Universal Declaration of Human Rights. See Benjamin F. Krolikowski, Brown v. Plata: The Struggle to Harmonize Human Dignity with the Constitution, 33 PACE L. Rev. 1255, 1257-68 (2013) (outlining the emergence of human dignity in Supreme Court jurisprudence in the post-World War II era).
} 
the death penalty, ${ }^{81}$ and establish certain affirmative rights for prisoners, such as the right to medical care. ${ }^{82}$ In the twenty-first century, the concept of human dignity has perhaps most strongly been expressed in relation to prisoner rights in Brown v. Plata, a case dealing directly with the humanitarian consequences of overcrowding and mass incarceration in California leading to serious harm, death, and degradation of incarcerated people in the state. ${ }^{83}$ In Plata, human dignity received explicit and important emphasis. Writing for the majority, Justice Anthony Kennedy concluded, "Prisoners retain the essence of human dignity inherent in all persons. Respect for that dignity animates the Eighth Amendment prohibition against cruel and unusual punishment." 84

The Court in Plata reasserted the fact that when the state incarcerates people, it deprives them of their ability to provide basic life necessities to themselves. As a result, the state's failure to provide such necessities "may actually produce physical torture or a lingering death." ${ }^{, 55}$ Importantly, the Court observed that where the state has failed to live up to its duty to provide for basic human needs, the courts must step in to protect the rights of incarcerated people. ${ }^{86}$ The Plata decision both underscores the fact that human dignity animates the Eighth Amendment and that courts must step in when the government undermines and endangers that dignity through its acts and omissions.

I do not want to suggest that litigating for menstrual equity rights in carceral settings is a simple matter or a slam-dunk win. Americans - and by extension the courts - have repeatedly treated the rights of people deprived of their liberty in prisons and jails as less worthy of care and respect. ${ }^{87}$ Indeed, it is hard to imagine that a nation with the world's highest incarceration rate - the United States has less than five percent of the world's

${ }^{81}$ Furman v. Georgia, 408 U.S. 238, 258, 270 (1972) (Brennan, J., concurring) (explaining that punishment is "cruel and unusual" under the Eighth Amendment when "it does not comport with human dignity").

${ }^{82}$ Estelle v. Gamble, 429 U.S. 97, 102 (1976) (noting that the Eighth Amendment "embodies broad and idealistic concepts of dignity, civilized standards, humanity, and decency ...”).

${ }^{83}$ Brown v. Plata, 131 S.Ct. 1910, 1923 (2011).

${ }^{84} I d$.

${ }^{85}$ Id. at 1928 .

${ }^{86} I d$. at 1929.

${ }^{87}$ See generally Sharon Dolovich, Exclusion and Control in the Carceral State, 16 BERKELEY J. CRIM. L. 259 (2001) (pointing to connections between America's system of mass incarceration and the general view in public and legal discourse that prisoners are less worthy of protection and care; essentially that they are allotted a sub-human status in our society). 
population but incarcerates about twenty percent of the world's incarcerated people ${ }^{88}$ actually embodies human dignity in our law, policy and practice on a consistent basis. And, certainly, the failure of the courts to protect incarcerated people from the ravages and mass deaths of the COVID-19 pandemic, despite the many lawsuits brought to force systems to decarcerate and take appropriate measures to stop the spread of the disease, is symptomatic of a troubling abdication of responsibility and concern for the health, safety, and rights of vulnerable populations. ${ }^{89}$ There are giant hurdles to any litigation strategy on behalf of incarcerated people.

But the menstrual equity movement provides a possible model for social change and legal development that both centers the rights of the many-women and girls and all people who menstruate - with a particular concern and focus on the rights of the uniquely vulnerable within the larger group, such as incarcerated people, poor youth, and people without housing. The overlay is recognizing the worth of human dignity and the government supports necessary to ensure that such dignity can be achieved by everyone. Pairing this social movement with a social critique and a robust commitment to social change through legislation, litigation, and activation of the community is how we evolve to a better standard of decency.

\footnotetext{
${ }^{88}$ Peter Wagner \& Wanda Bertram, "What Percent of the U.S. Is Incarcerated" (And Other Ways to Measure Mass Incarceration), PRISON POL'Y INITIATIVE (Jan. 16, 2020), https://www.prisonpolicy.org/blog/2020/01/16/percent-incarcerated/ [https://perma.cc/77VP-BUKZ].

${ }^{89}$ See generally Roni Caryn Rabin, Vulnerable Inmates Left in Prison as Covid Rages, N.Y. Times (Feb. 27, 2021), https://www.nytimes.com/2021/02/27/health/coronavirus-prisons-danbury.html; Andrea Woods, Federal Judges Are Failing Incarcerated People During the Pandemic, ACLU (Sept. 20, 2020), https://www.aclu.org/news/criminal-law-reform/federal-judges-are-failing-incarcerated-people-during-thepandemic/ [https://perma.cc/2C7D-BFY7].
} 